\title{
OS EFEITOS DA UNIFICAÇÃO DO REGIME DAS OBRIGAÇÕES PELO CÓDIGO CIVIL DE 2002: ESTUDO DO CONTRATO DE COMODATO NA RELAÇÃO DE DISTRIBUIÇÃO DE DERIVADOS DE PETRÓLEO
}

EFFECTS OF THE UNIFICATION OF THE OBLIGATION'S REGIME BY THE 2002 CIVIL CODE: STUDY OF THE COMMODATE CONTRACT IN THE RELATION OF OIL 'S

DERIVATIVE DISTRIBUTION

\section{Luciano Zordan Piva*}

Sumário: Introdução. 1. A dualidade Direito Civil - Direito Comercial como base da pesquisa. 1.1. Apontamentos sobre a evolução histórica da unificação do Direito Privado brasileiro. 1.2. Técnica de pesquisa e corte metodológico: o contrato de comodato na relação de distribuição de derivados de petróleo. 1.3. Da utilização do contrato de comodato como paradigma para a investigação: contrato tipicamente civil numa relação empresarial. 2 . Resultados: inclinação jurisprudencial no sentido de evidenciar a autonomia do direito comercial. 2.1. Análise das decisões que consideram o contexto de inserção do contrato para configuração da sua função social e econômica típica. 2.2. Relação de decisões que aplicaram regras civis ao contrato de comodato inserido na relação de distribuição de derivados de petróleo. 2.3. Análise de decisões anteriores à vigência do Código Civil de 2002. 3. Um novo código comercial é necessário? Considerações finais. Referências.

Resumo: Uma das maiores transformações promovidas pelo Código Civil foi concretizar a tendência histórica do Direito brasileiro no sentido da unificação do regime das obrigações. Tendo em conta os dez anos de vigência da "constituição do homem comum", esse artigo procura identificar as consequências práticas da unificação, isto é, examinar qual o impacto provocado nos julgamentos de casos envolvendo situações limites, em que, por exemplo, um contrato civil típico tenha sido utilizado numa operação intrinsecamente empresarial. Nesse sentido, analisar-se-á o contrato de comodato inserido na atividade de distribuição de derivados de petróleo, sempre atento aos novos dispositivos do Código Civil que originaram regras para a solução de casos como o supramencionado. Aproveitando as indispensáveis reflexões acerca da dualidade Direito Civil - Direito Comercial para a produção desse artigo,

\footnotetext{
* Universidade Federal do Rio Grande do Sul.
} 
ao final provoca-se a discussão a respeito da necessidade ou não de um novo Código Comercial, em virtude da proposta do Projeto de Lei n. 1.572, de 2011.

Palavras-chave: Direito Comercial; Código Civil; Unificação das Obrigações; Comodato; Projeto de Código Comercial.

Abstract: One of the most important changes promoted by the Civil Code was to materialize the historical tendency of Brazilian Law towards the unification of Obligation's regime. Taking into account the ten years of entering into force of this Code, this paper aims to identify the practical consequences of the unification, that is to say, to examine what is the real impact provoked in the trials involving threshold situations between Civil Law and Commercial Law, as for example, when a typical civil contract has been used in an intrinsically commercial transaction. In this sense, it shall be analyzed the commodate contract inserted in the oil's derivative distribution activity, always looking up to the Civil Code new provisions that originated rules for the solution of cases like the above-named. Taking the indispensable reflections about the duality between Civil Law - Commercial Law, in the end of this paper, we provoke a discussion about the necessity of a new Commercial Code, due to the recent 2011 Draft Bill n. 1.572.

Keywords: Commercial Law; Civil Code; Unification of Obligation's Regime; Commodate Contract; Draft of Commercial Civil Code.

"Há em cada empresa, afeição ou idade um ciclo inteiro da vida humana”. (MACHAdo DE Assis, Memórias póstumas de Brás ubas). 


\section{INTRODUÇÃO}

Para MACHAdo DE ASsiS e para a História do Direito ${ }^{1}$, dez anos pode não ser considerado um tempo de análise razoável para verificar o impacto transformador de uma nova regulamentação para a sociedade. Segundo o autor brasileiro, cada evento vivido contém em si o tempo de toda uma vida, e, para a História do Direito, sua missão é "antes a de problematizar o pressuposto implícito e acrítico das disciplinas dogmáticas", como afirma ANTÓNIO MANUEL HESPANHA 2 .

Entretanto, para o Direito na História, dez anos já podem demonstrar a evolução dos efeitos na sociedade oriundos de uma nova regulamentação. Assim, através de uma perspectiva macrojurídica ${ }^{3}$, em que se levam em conta os efeitos da regulamentação na economia global da sociedade, esse artigo ambiciona verificar e analisar a variação na aplicação legislativa das decisões dos Tribunais, a fim de perquirir as consequências da unificação do regime das obrigações, bem como os seus efeitos para a sociedade, no transcorrer desses dez anos desde a edição do Código Civil brasileiro vigente.

Se a tarefa é extensa, o corte metodológico realizado através da pesquisa de casos específicos relacionados ao Direito Comercial não diminui a importância do tema ${ }^{4}$. Pelo contrário, afunilar o campo de análise demanda uma execução ainda mais cuidadosa, tendo em vista a responsabilidade em verificar os efeitos de cada caso à luz de uma nova legislação.

\footnotetext{
${ }^{1}$ Esse artigo resultou da investigação científica realizada no Grupo de Pesquisa CNPQ "O Regime da Autonomia Privada, Liberdade de Iniciativa e Função Social nos Contratos Empresariais", coordenado pelo Prof. Dr. Gerson Luiz Carlos Branco, na Faculdade de Direito da UFRGS. Fundamental, também, a concessão pela UFRGS de bolsa de Iniciação Científica para o desenvolvimento e apresentação da pesquisa. O autor agradece, outrossim, aos Professores Lisiane Ody, Jorge Cesa Ferreira da Silva e Eugênio Facchini Neto pelas críticas e pelos comentários feitos por ocasião da apresentação no Salão de Iniciação Científica da Faculdade de Direito da UFRGS.

${ }^{2}$ HESPANHA, António Manuel. Panorama histórico da cultura jurídica europeia. Lisboa: Publicações EuropaAmerica, 1997, p. 15. Ainda sobre História do Direito, ilustrativa a doutrina do Prof. Waldemar Ferreira: "Não consiste a história do direito, por certo, na súmula cronológica das leis que lhe tomaram a essência e enredaram a trama dos institutos em que se cristalizou. Trabalho seria esse a um tempo de paciência e de cópia, nem sempre de valor histórico pela existência de inúmeras leis e atos de governo de apoucada valia para a história do direito. Pode esta certamente ocupar-se de certos institutos que sem a sua coadjuvança poderiam parecer esdrúxulos e permanecer incompreendidos. Diversos títulos do direito seriam ininteligíveis a não ser quando encarados à luz da história, pois é da história que lhes vem o impulso que configurará seu desenvolvimento subsequente". FERREIRA, Waldemar. A História do Direito nos Cursos Jurídicos do Brasil. Revista da Faculdade de Direito da USP, São Paulo, vol. XLV, "Fascículo em honra do Professor Waldemar Ferreira", 1950, p. 445.

${ }^{3}$ MARTINS-COSTA, Judith. O regime dos juros no novo direito privado brasileiro. Revista da AJURIS, Porto Alegre, v. 34, n. 105, mar. 2007, p. 241.

4 "No caso do direito comercial, desafiar o gosto pela pesquisa histórica assume caráter ainda mais complexo. Convencer da importância de conhecimentos distantes perante o dinamismo da economia e do tráfico comercial atual soa aparentemente irrazoável. Inúmeras razões levam a crer, entretanto, que um eventual desestímulo mais diz com o equívoco da abordagem do tema, do que com seu conteúdo". MIRAGEM, Bruno N. B. Do direito comercial ao direito empresarial. Formação histórica e tendências do direito brasileiro. Revista de Direito Privado, v. 5, n. 17, jan.-mar./2004, p. 56.
} 


\section{Cadernos do Programa de Pós-Graduação em Direito/UFRGS}

E nessa perspectiva, o Direito Empresarial é rico em casos, consequências e efeitos, ${ }^{5}$ embora deve-se deixar claro que a pesquisa jurisprudencial teve um caráter qualitativo e não puramente quantitativo: foram selecionadas aquelas decisões judiciais representativas do objeto da investigação.

Um grande grupo desses casos diz respeito à utilização de diversos tipos de contratos, oriundos tanto do Direito Civil, como da atividade comercial. Muito devido ao fenômeno conhecido como "comercialização do Direito Civil", esses contratos passaram a ser considerados como integrantes de uma rede conexa de contratos (conexão contratual) ${ }^{6}$, atenuando os limites existentes entre o Direito Comercial e o Direito Civil, e acentuando a histórica tendência do ordenamento jurídico brasileiro para uma unificação das obrigações civis e mercantis ${ }^{7}$.

Muitos são os exemplos que expressam essa dualidade entre Direito Civil e Direito Comercial, tais como a "multifuncionalidade do contrato de compra e venda" , a possibilidade de a locação ser civil ou comercial, os contratos nominados tipificados no Código Civil que regulam atividades empresariais (comissão, agência, seguro e transporte).

Mais especificamente, um exemplo que se destaca é o do contrato de distribuição de derivados de petróleo. Na prática, ele envolve uma rede complexa de contratos integrados para atingir a atividade comercial fim de distribuição, todavia, vale-se para isso de contratos tipicamente civis, como o contrato de comodato, objeto da nossa análise no presente artigo.

O interesse em analisar o contrato de comodato, instituto civil típico, numa relação evidentemente comercial, como é o caso da distribuição de derivados de petróleo, justifica-se

\footnotetext{
5 "O direito comercial não existe sem julgados; e, por sua vez, o resultado dessa corrente de decisões condiciona a atuação dos agentes econômicos, fechando um ciclo que não pode ser ignorado pelo intérprete do Direito". FORGIONI, Paula A. A unicidade do regramento jurídico das sociedades limitadas e o art. 1.053 do CC. Usos e costumes e regência supletiva. Revista de Direito Mercantil, vol. 147, Jul./Set. 2007, p. 7.

${ }^{6}$ Ao julgar a Apelação Cível n. 79.863, em 10.10.1972, o relator Des. Antônio Pereira Pinto bem discorreu a respeito da conexão contratual: "Quando as prestações características dos contratos de comodato (de equipamentos e utensílios) e de compra e venda (de gasolina) se encontram em relação de recíproca 'coordenação', temos um contrato misto, pois o que o configura é a coexistência de obrigações pertinentes a tipos diferentes de contratos enlaçados pelo caráter unitário da operação econômica”. Tribunal de Justiça da Guanabara.

${ }^{7}$ Sylvio Marcondes já acenava para essa tendência na exposição de motivos do Anteprojeto de Código de Obrigações, apresentado em junho de 1964: "A elevação e disseminação da cultura, o enorme progresso científico, a expansão da produção e circulação de toda sorte de bens, conduzem a um processo de democratização da riqueza, favorável à multiplicação dos atos econômicos e da sua prática por pessoas em número cada dia maior. Negócios jurídicos quase privativos de uma classe, como a dos comerciantes, passam a constituir rotina cotidiana de todos. Acelera-se o que, tão ao gosto da doutrina francesa, se tem admitido chamar 'comercialização do direito civil', corroborando um 'civilismo do direito comercial'.". MARCONDES, Sylvio. Problemas de Direito Mercantil. São Paulo: Max Limonad, 1970, p. 130.

${ }^{8}$ BRANCO, Gerson Luiz Carlos. O regime obrigacional unificado do Código Civil brasileiro e seus efeitos sobre a liberdade contratual. A compra e venda como modelo jurídico multifuncional. Revista dos Tribunais, a. 97, v. 872 , jun./2008, p. 11-42.
} 
exatamente porque, sob a veste de ser uma categoria histórica ${ }^{9}$, o Direito Empresarial coexistiu ao lado do Direito Civil como um direito especial. Isto é, por muitos anos, as roupas do Direito Empresarial foram giacca e cravatta, numa alusão ao direito de uma determinada categoria profissional: os comerciantes.

Muito em razão da tendência de o Direito Civil apresentar certa superioridade científica em relação ao Direito Comercial, visto que naquele "prevalecem as exigências de uma profunda coesão e de uma disciplina sistemática dos conceitos mais gerais", como afirma CESARE VIVANTE ${ }^{10}$, o Direito Comercial foi, em verdade, um direito tão somente aplicado - e estudado - no ambiente de negócios ${ }^{11}$.

Aliado a isso - a reclusão acadêmica do Direito Comercial $^{12}$-, no sistema jurídico brasileiro, desenvolvia-se a ideia de promulgar um Código Civil que fosse "eixo do Direito Privado"13, daí que, com a edição da Constituição de 1988 e a retomada de confiança do legislador brasileiro, um Projeto que desde os anos 70 vinha sendo lapidado e postergado pode ser retomado para, em 2002, ser promulgado. Entrava em vigor, em 2003, o Código

\footnotetext{
${ }^{9}$ A constatação de que nunca existiram critérios precisos para, cientificamente, delimitar o Direito Civil e o Direito Comercial é hoje acatada por grande parte da doutrina. Especificamente, quem melhor explicou a evolução do Direito Comercial desde sua origem foi TULLIO ASCARELLI: "É na civilização das comunas que o Direito Comercial começa a afirmar-se, em contraposição à civilização feudal, mas também distinguindo-se do Direito Romano comum que, quase simultaneamente, se constitui e se impõe. O Direito Comercial aparece, por isso, como um fenômeno histórico, cuja origem é ligada à afirmação de uma civilização burguesa e urbana, na qual se desenvolvem um novo espírito empreendedor e uma nova organização dos negócios". ASCARELLI, Tullio. Origem do direito comercial. Trad. e notas de Fabio Konder Comparato. Revista de direito mercantil, industrial, econômico e financeiro, nova série, v. 35, n. 103, jul./set. de 1996, p. 88.

${ }^{10}$ VIVANTE, Cesare. Tratado de direito comercial. v. 1 (Introdução: "Os comerciantes"). Tradução em VIVANTE, Cesare. Introdução: Os comerciantes. Trad. Haroldo Malheiros Duclerc Verçosa. Revista de direito mercantil, industrial, econômico e financeiro, n. 102, abr.-jun./1996, p. 109.

${ }^{11}$ Todavia, juristas como o gaúcho HERNANI EsTRELLA consideravam como essencial a intersecção entre o Direito Comercial e as ciências econômicas, que dariam substrato necessário para o ofício regulatório: "Partindo de dados fornecidos pela ciência econômica, a ciência jurídica poderá construir os quadros legais que facilitarão a produção e a circulação dos bens, sempre consideradas, uma e outra, em relação aos indivíduos. Esta foi, e parece continuar a ser, a missão a que foi chamado a desempenhar o Direito Comercial". ESTRELLA, Hernani. Comercialização do Direito Civil. Revista Forense, n. 185, 1957, p. 86.

${ }^{12}$ Inclusive, retrata-se CESARE VIVANTE, na introdução de seu Tratado de Direito Comercial, vol. I, a respeito da proposta de reunir o Direito Comercial ao Direito Civil em um único Código, afirmando que essa teve inspiração no "embaraço científico no qual se encontrava nossa disciplina, condenada a viver a meio caminho entre o empirismo da prática e as doutrinas tradicionais consagradas pelo Direito Civil, bloqueando-se na impotência jurídica dos contratos sui generis". E prossegue: "Mas a minha frequente participação nas reformas legislativas e, especialmente, na do Código de Comércio, durante os numerosos anos transcorridos desde a mencionada iniciativa, convenceram-me de que aquela fusão dos dois códigos em um único teria trazido um grave prejuízo ao progresso do direito comercial". VIVANTE, Cesare. Introdução: Os comerciantes. Trad. Haroldo Malheiros Duclerc Verçosa. Revista de direito mercantil, industrial, econômico e financeiro, n. 102, abr.-jun./1996, p. 108. ${ }^{13}$ BRANCO, Gerson Luiz Carlos. Função Social dos Contratos: interpretação à luz do Código Civil. São Paulo: Saraiva, 2009, p. XXXI, da Introdução. Nas palavras do Coordenador do Anteprojeto, Professor Miguel Reale: "lei básica, mas não global, do direito privado". REALE, Miguel. O Projeto de Código Civil: situação atual e seus problemas fundamentais. São Paulo: Saraiva, 1986, p. 71.
} 
Civil, revogando o antigo Código Civil de 1916, arraigado em um substrato social totalmente distinto, e parte considerável do vetusto Código Comercial de 1850.

O Código Civil de $2002^{14}$, embora com diversas novidades principalmente na sua Parte Geral e na parte concernente ao Direito de Família ${ }^{15}$, deve à unificação das obrigações civis e mercantis o posto de grande inovação promovida. Isso porque a unificação do regime obrigacional, pelo menos no que tange à possibilidade de concretizá-la no plano regulatório, foi movimento histórico nascido no direito brasileiro ${ }^{16}$, especialmente nas ideias precursoras de TEIXEIRA DE FREITAS.

Assim, para que as pretensões desse texto sejam atendidas, a primeira parte do artigo volta-se para traçar o panorama histórico que albergou a possibilidade da concretização da unificação do regime obrigacional, movimento delineado há pelo menos 130 anos no cenário jurídico nacional.

Todavia, ao invés de limitar-se a reflexões históricas acerca do tema, o texto, na segunda parte, avança para o ponto central da pesquisa desenvolvida, qual seja a análise empírica das decisões dos principais Tribunais brasileiros ao julgarem casos de Direito Comercial - TJ/RS, TJ/SP, TJ/RJ -, a fim de verificar se a mudança no plano legislativo acarretou alterações substanciais na orientação jurisprudencial.

${ }^{14}$ É de se ressaltar, entretanto, que alguns doutrinadores não consideram essa expressão "novo Código" como verdade absoluta, uma vez que o tempo entre o Projeto inicial - datado de 1975 - e a promulgação do Código Civil ultrapassou 23 anos. Nesse sentido, RACHEL SzTAJN: "Demais disso, anote-se o significativo lapso temporal que medeia entre a última versão do anteprojeto e a redação final do Código Civil, sem que se atentasse para as significativas mudanças da base social sobre a qual a lei se aplica, o desenvolvimento da economia incluído o agronegócio, com o que deixaram de ser pensados os incentivos corretos para que as fricções sociais fossem reduzidas”. SZTAJN, Rachel. Codificação, decodificação, recodificação: a empresa no Código Civil Brasileiro. Revista de Direito Mercantil, vol. 143, jul./set. 2006, p. 11.

${ }^{15}$ Como definiu o Coordenador-Geral do Código, o Professor Miguel REALE: "Se considerarmos que, depois, houve a apreciação de mais de mil emendas na Câmara dos Deputados, e de mais de quatrocentas no Senado Federal, com novo retorno à Câmara dos Deputados, para novos estudos e discussões, pode-se proclamar o caráter coletivo que veio assumindo o Projeto, não se perdendo, ao longo de mais de três décadas, oportunidade alguma para atualiza-lo, em razão de fatos e valores supervenientes, como se deu, por exemplo, com as profundas alterações que a Constituição de 1988 introduziu em matéria de Direito de Família”. REALE, Miguel. Visão geral do novo Código Civil. Jus Navigandi, Teresina, ano 7, n. 54, 1 fev. 2002. Disponível em: <http://jus.com.br/revista/texto/2718>. Acesso em: 13 dez. 2011.

${ }^{16}$ Reconhece-se que a doutrina alemã já realizava estudos sobre o assunto desde o séc. XVII, como leciona o Professor NORBERTO MAC-DONALD: “A partir do Código Comercial alemão de 1861, passa-se a favorecer o comerciante. A nova orientação teve vasta e crescente difusão com a progressiva ascensão da classe mercantil: no conflito entre os dois Códigos, prevalecia o Direito Comercial, cujo campo de aplicação adquiriu amplas proporções. (...) "A tendência expansiva do Direito Comercial no continente europeu manifesta-se sob dúplice aspecto: - extensão do campo de aplicação dos códigos comerciais (das relações entre comerciantes, segundo o modelo francês, passam a regular as relações mistas, segundo o modelo alemão); - comercialização, em diversos graus, dos Códigos Civis, com o acolhimento, para regular relações também entre não comerciantes, de alguns princípios originariamente próprios das relações comerciais". MAC-DONALD, Norberto da Costa Caruso. A unificação do direito das obrigações no novo código civil. Revista Síntese de Direito Civil e Processual Civil, Porto Alegre, v. 4, n. 20, nov./dez. 2002, p. 27-40. Todavia, os estudos de TEIXEIRA DE FreITAS conseguiram reunir considerações no âmbito regulatório, ao passo que os alemães, especificamente quanto à unificação das obrigações, restringiram-se tão somente à questão doutrinária. 


\section{Cadernos do Programa de Pós-Graduação em Direito/UFRGS}

Por fim, em razão da tramitação, no Congresso Nacional, do Projeto de Lei n. 1.572 que encaminha proposta de um novo Código Comercial, a terceira parte desse artigo propõe-se a examinar o cabimento e a real necessidade dessa medida legislativa, tendo em vista os resultados da pesquisa jurisprudencial que relaciona a aplicação do novo Código Civil a casos tipicamente empresariais (distribuição de derivados de petróleo).

\section{A DUALIDADE DIREITO CIVIL - DIREITO COMERCIAL COMO BASE DA PESQUISA}

\subsection{Apontamentos sobre a evolução histórica da unificação do Direito Privado brasileiro}

Em oposição ao Código Comercial de 1850, promulgado às pressas devido à ansiedade dos comerciantes cariocas em ter alguma regulação frente ao dinâmico mercado do século XIX $^{17}$, o Código Civil de 1916 teve origem em mandamento constitucional, visto que a Constituição Federal de 1824 determinava a organização de um Código Civil ${ }^{18}$.

Na ocasião, TEIXEIRA DE FREITAS fora contratado pelo Governo Imperial para realizar trabalho preparatório para o que seria o futuro Código Civil. Surge, em 1857, a Consolidação das Leis Civis, pedra fundamental do que seria o famoso Esboço de Teixeira de Freitas.

Tal Esboço, como afirma o próprio autor, tinha como objetivo "a feitura de um Projeto de Código Civil para reger como subsídio ao complemento de um Código do Comércio"19. Imiscuído nessas ideias, TEIXEIRA DE FREITAS propõe, em 1867, a elaboração de dois Códigos: "o Geral que contivesse, quanto às causas e aos efeitos jurídicos, as noções preliminares que serviriam para a interpretação das leis; e o Civil, em que se unificaria o direito privado com a unificação das normas de direito civil e de direito comercial" 20 . A explanação do jurista não deixa dúvidas quanto a sua intenção:

"Não há mesmo alguma razão de ser para tal seleção de Leis; pois que, em todo o decurso dos trabalhos de um CC aparecem raros casos, em que seja de mister

\footnotetext{
${ }^{17}$ Um bom panorama histórico sobre o ativo comércio do Rio de Janeiro no século XIX é apresentado por JORGE CALDEIRA na obra Mauá, Empresário do Império. São Paulo: Companhia das Letras, 1995.

${ }^{18}$ MOREIRA ALVES, José Carlos. A Unificação do Direito Privado Brasileiro - de Teixeira de Freitas ao Novo Código Civil. In: JUNQUEIRA DE AZEVEDO, Antônio (Org.). Princípios do Novo Código Civil Brasileiro e Outros Temas: homenagem a Tullio Ascarelli. São Paulo: Quartier Latin, 2008, p. 310.

${ }^{19}$ FERREIRA COELHO. Código Civil dos Estados Unidos do Brasil. v. I (Formação do Direito Escrito). n. 613. Rio de Janeiro: Oficinas Gráficas do "Jornal do Brasil”, 1920, p. 267. Apud MOREIRA ALVES. Op. cit., p. 312.

${ }^{20}$ MOREIRA ALVES. Op. cit., p. 313.
} 


\section{Cadernos do Programa de Pós-Graduação em Direito/UFRGS}

distinguir o fim comercial dos atos, por motivo da diversidade nos efeitos jurídicos"21.

Apesar de receber parecer favorável da Seção de Justiça do Conselho de Estado, o Governo Imperial não aprovou a elaboração dos dois Códigos, como propunha TEIXEIRA DE FREITAS. Por essa razão, seu contrato acabou sendo rescindindo, e a sua inovadora ideia postergada cerca de 130 anos.

Todavia, o legado deixado por "um dos maiores jurisconsultos da latinidade moderna"22 influenciou pelo menos três relevantes Projetos de regulação que tinham como objetivo a unificação do direito privado.

Em 1911, a INGLÊS DE SOUZA fora delegada a tarefa de redigir um projeto de unificação do direito privado, bem como um Projeto que teria como ambição substituir o Código Comercial de $1850^{23}$. Nenhum dos projetos prosperou e, em 1915, o Projeto de Código Civil de Clóvis Bevilaqua, fora aprovado pelo Congresso.

Ainda no século XX, em 1940, um projeto de Código de Obrigações fora colocado em pauta para elaboração por três juristas: Orozimbo NonAto, PhiladelPho AzEvedo e HAHNEMANN GuIMARÃES. Como pano de fundo, estava a ideia de "unificar os princípios gerais sobre as obrigações e a disciplina dos contratos em espécie", a fim de "resolver o problema da reforma do direito mercantil, que ficará, assim, reduzido a um restrito núcleo de preceitos reguladores da atividade profissional dos comerciantes; a matéria relativa às sociedades e ao transporte comportará, ainda, codificações autônomas" ${ }^{24}$. Apesar de explicitamente ressalvarem a manutenção do Direito Comercial ${ }^{25}$, o Projeto não prosperou devido às críticas de comercialistas que temiam a extinção dessa área do Direito.

A ideia da unificação só voltaria à tona com a proposição de CAIO MÁRIO DA SILVA Pereira, Sylvio Marcondes e Theófilo SAntos em unificar o direito obrigacional tal qual o modelo suíço à época vigorava ${ }^{26}$. Em específico, CAIO MÁRIO DA SILVA PEREIRA era

\footnotetext{
${ }^{21}$ FERREIRA COELHO. Código Civil dos Estados Unidos do Brasil. v. I (Formação do Direito Escrito). n. 613. Rio de Janeiro: Oficinas Gráficas do "Jornal do Brasil", 1920, p. 267.

${ }^{22}$ CARVALHO, Orlando de. Teixeira de Freitas e a unificação do direito privado. Boletim da Faculdade de Direito de Coimbra, n. 60, 1984, p. 3.

${ }^{23}$ MOREIRA ALVES, José Carlos. A Unificação do Direito Privado Brasileiro - de Teixeira de Freitas ao Novo Código Civil. In: JUNQUEIRA DE AZEVEDO, Antônio (Org.). Princípios do Novo Código Civil Brasileiro e Outros Temas: homenagem a Tullio Ascarelli. São Paulo: Quartier Latin, 2008, p. 317.

${ }^{24}$ NONATO, Orozimbo; AZEVEDO, Philadelpho; GUIMARÃES, Hahnemann. Anteprojeto de Código de Obrigações (Parte Geral), n. 2, 1941, p. 5. Apud MOREIRA ALVES, op. cit., p. 320.

25 "Com a unificação do direito das obrigações, o direito comercial não desaparecerá; não desaparecerá o Código Comercial”. Idem, p. 67.

${ }^{26}$ À semelhança do modelo suíço, cabia a Orlando Gomes a elaboração de um novo Código Civil.
} 


\title{
Cadernos do Programa de Pós-Graduação em Direito/UFRGS
}

enérgico quanto à necessidade de cristalizar a proposta lançada anteriormente por TEIXEIRA DE FREITAS:

\begin{abstract}
Este Projeto, com tais características, se convertido em lei porá o Brasil na linha dos sistemas contemporâneos que repelem a dicotomia incongruente do Direito Privado, e consagrará uma ideia, que antes de ser posta em prática na codificação de sistemas jurídicos de povos do mais elevado conceito, já era nossa, preconizada que fora, antes de todos, pelo mais genial de nossos civilistas, Teixeira de Freitas ${ }^{27}$.
\end{abstract}

Fulminado por críticas na parte correspondente ao Direito de Família no Código Civil, o Governo acabou por retirar ambos os $\operatorname{Projetos}^{28}$.

Por essas razões, somente após 122 anos da inovadora proposta de TEIXEIRA DE FREITAS um Projeto com semelhante intenção prosperou: em 1969, a Comissão para o Anteprojeto do Código Civil, liderada por Miguel Reale, iniciava os trabalhos que resultariam no Código Civil de 2002, cuja principal mudança em relação ao Código Civil de 1916 estava justamente na unificação do direito privado, mediante o regramento único da disciplina das Obrigações.

\subsection{Técnica de pesquisa e corte metodológico: o contrato de comodato na relação de distribuição de derivados de petróleo}

A técnica de pesquisa utilizada trouxe, numa primeira busca, uma gama considerável de "casos-limite", em que a dualidade civil-comercial estava presente, tendo em vista a impossibilidade de delimitar uma única disciplina ao regramento de situações como no caso do contrato de compra e venda (que pode ser mercantil, civil ou consumerista) ${ }^{29}$, o contrato de locação, que poder ter características civis ou comerciais, e ainda alguns contratos nominados no Código Civil que regulam atividades tipicamente empresariais, como os de seguro, transporte, comissão e agência. Daí a necessidade de empregar um corte metodológico, a fim de extrair, dentre as possibilidades encontradas, apenas uma categoria e sobre ela traçar distinções, o que, ao fim e ao cabo, é a tarefa principal do pesquisador de Direito ${ }^{30}$.

\footnotetext{
${ }^{27}$ PEREIRA DA SILVA, Caio Mário. A unidade do direito obrigacional. Revista Forense, v. 97, p. 5. Apud MOREIRA ALVES, José Carlos. A Unificação do Direito Privado Brasileiro - de Teixeira de Freitas ao Novo Código Civil. In: JUNQUEIRA DE AZEVEDO, Antônio (Org.). Princípios do Novo Código Civil Brasileiro e Outros Temas: homenagem a Tullio Ascarelli. São Paulo: Quartier Latin, 2008, p. 329.

${ }^{28}$ MOREIRA ALVES. Op. cit., p. 330.

${ }^{29}$ Sobre a multifuncionalidade do contrato de compra e venda, v. BRANCO, G. L. C. O regime obrigacional unificado do Código Civil brasileiro e seus efeitos sobre a liberdade contratual. A compra e venda como modelo jurídico multifuncional. Revista dos Tribunais, a. 97, v. 872, jun./2008, p. 11-42.

${ }_{30}$ Além de traçar distinções, cumpre ao pesquisador, no âmbito do Direito, vestir as roupas do historiador que, nas palavras do Professor PAOLO GROSSI, tem "um papel exclusivo: civilização significa história, um contexto histórico determinado em toda a riqueza de suas expressões. E é prática característica do historiador a de colocar o dado que opera no interior do contexto que o gerou e que lhe imprime vida. É o historiador quem pode e deve
} 


\section{Cadernos do Programa de Pós-Graduação em Direito/UFRGS}

Relevante para a especialização do objeto de análise foi o texto clássico do comercialista ARNOLDO WALD que, em 1979, publicou o parecer "Os contratos de concessão exclusiva para distribuição de gasolina no Direito brasileiro" ${ }^{31}$. A obra citada refere-se, em síntese, aos diversos contratos celebrados entre distribuidores de derivados de petróleo com os revendedores (postos de gasolina). A principal crítica apresentada no parecer dirigia-se às empresas distribuidoras (“distribuidores"), tendo em vista que essas se valiam do conjunto de contratos integrados (complexo de contratos que viabilizavam a operação econômica de distribuição) para manterem o vínculo com as empresas revendedoras ("revendedores"), mesmo sob condições ilícitas e contratualmente desproporcionais.

Não obstante a pioneira linha de pensamento de ARNOLDO WALD no que concerne à reflexão a cerca do princípio da função social (ainda que sem mencionar expressamente tal princípio), o comercialista não se deteve em analisar a coligação contratual existente entre os diversos contratos que se integram na relação de distribuição de derivados de petróleo. Isso se torna relevante na medida em que, in casu por força do conteúdo contratual, os contratos "encontram-se em relação de dependência unilateral ou recíproca" 32 , gerando obrigações acessórias que vinculam os contratantes independentemente de a relação principal ser comercial ou civil. A justificativa para a vinculação está, nesse sentido, no nexo funcionaleconômico $^{33}$ que tais contratos estabelecem na relação de distribuição de derivados de petróleo, sendo necessário para o perfeito adimplemento da obrigação principal contida no contrato de distribuição.

A partir dos estudos debatidos no Grupo de Estudos "Obrigações e Contratos Mercantis" e no Grupo de Pesquisa "O Regime da Autonomia Privada, Liberdade de Iniciativa e Função Social nos Contratos Empresariais”, na Faculdade de Direito da UFRGS, iniciou-se a pesquisa de jurisprudência pautada pela seguinte pergunta: a natureza da relação obrigacional subjacente seria relevante para a aplicação de determinado modelo jurídico?

recordar aos privatistas e publicistas - todos eles presos nos próprios textos legislativos - o fato de que o texto em si é sempre uma representação de uma realidade de fundo, uma representação parcial e artificiosa por somatória". Sendo assim, lembrando essa preciosa lição, cumpre mergulhar no denso universo das obrigações civis e mercantis para "apreciar a substância efetiva do fenômeno" regulado pelo Código Civil de 2003. Os trechos foram extraídos de GROSSI, Paolo. O Ponto e a Linha. História do Direito e Direito Positivo na Formação do Jurista do Nosso Tempo. Tradução de Mônica Sol Glik. Revista Sequencia, n. 51, Dez. 2005, p. 31 45.

${ }^{31} \mathrm{O}$ texto original está publicado em WALD, Arnoldo. Os contratos de concessão exclusiva para distribuição de gasolina no direito brasileiro. Estudos e pareceres de direito comercial - problemas comerciais e fiscais da empresa contemporânea. $2^{\mathrm{a}}$ série. São Paulo: Revista dos Tribunais, 1979.

${ }^{32}$ MARINO, Francisco Paulo De Crescenzo. Contratos Coligados no Direito Brasileiro. São Paulo: Saraiva, 2009 , p. 99.

${ }^{33}$ KONDER, Carlos Nelson. Contratos Conexos: Grupos contratuais, redes contratuais e contratos coligados. Rio de Janeiro: Renovar, 2006, p. 132. 


\section{Cadernos do Programa de Pós-Graduação em Direito/UFRGS}

Com isso, pretender-se-ia compreender se o contexto econômico-social em que determinada relação contratual se encontrava inserida determinaria o grupo de regras que incidiriam numa eventual discussão judicial daqueles $\operatorname{contratos}^{34}$, a fim de polarizar e determinar os riscos aos quais os empresários, cidadãos e a sociedade podem correr e quantificar para celebrar contratos de distribuição de derivados de petróleo $^{35}$.

Assim, inicialmente a investigação traçou três critérios para padronizar e aperfeiçoar a pesquisa de jurisprudência no site dos principais Tribunais que julgam casos envolvendo Direito Comercial ${ }^{36}$ : (i) especificar, na ferramenta de pesquisa, as palavras "contrato", "comodato", "distribuição" e "petróleo"; (ii) identificar o fundamento preponderante nos acórdãos para a construção do dispositivo nos casos em que o contrato tipicamente civil (e.g. comodato) estava inserido na relação comercial de distribuição de derivados de petróleo; e (iii) buscar decisões anteriores à vigência do Código Civil de 2003, a fim de traçar um paralelo com possíveis transformações na jurisprudência.

\subsection{Da utilização do contrato de comodato como paradigma para a investigação: contrato tipicamente civil numa relação empresarial}

Percebe-se, da leitura realizada até aqui, que a palavra "comodato" foi utilizada como critério de busca na pesquisa de jurisprudência. A justificativa para refinar ainda mais os parâmetros de pesquisa está relacionada à necessidade de afunilar o amplo campo de análise que a investigação acerca da dualidade civil - comercial oferece. Isso porque, o contrato de

\footnotetext{
${ }^{34}$ A Professora PAUla Forgioni desenvolveu pesquisa na Universidade de São Paulo com preocupações similares, quando procurou estabelecer parâmetros mínimos de interpretação nas hipóteses em que o contrato de distribuição era discutido no Poder Judiciário: "Quando se celebra um contrato atípico, não há a incidência de um regramento específico que discipline a relação entre as partes. De certa forma, isso gera insegurança, na medida em que não se tem certeza sobre a hipótese normativa que irá se compor e sobre as consequêencias jurídicas que serão produzidas". FORGIONI, Paula A. O posicionamento dos Tribunais perante os contratos de distribuição (1980 - 2000). EAESP/FGV/NPP - Núcleo de Pesquisas e Publicações, p. 9. Disponível em: $\langle$ http://gvpesquisa.fgv.br/sites/gvpesquisa.fgv.br/files/publicacoes/Rel\%2043-2001.pdf〉. Acesso em 02 de ago. de 2012. Pode-se acrescentar, ainda, que esse comentário esboça um dos principais motivos pelos quais a presente pesquisa ganha relevo, uma vez que das diversas variáveis "obscuras" do mercado, a possibilidade de estabelecer padrões razoáveis de interpretação das decisões é de fundamental importância para os empresários desenvolverem o seu ofício.

${ }^{35}$ Tal como lembra a Professora Rachel Sztajn: "Outro risco tão importante quanto o econômico, é denominado pelos economistas de 'risco jurídico' ou 'incerteza jurídica', pois, prende-se à legislação, à forma pela qual o Judiciário aplica ou interpreta os textos legais, à aderência das regras as instituições e práticas socialmente aceitas, sua estabilidade. (...). O risco jurídico, criado pela redação e interpretação das normas de direito positivo é menos aparente e mais difícil de estimar e, usualmente, não percebido pelos operadores do direito formados na visão formalista ou legalista do sistema". SZTAJN, Raquel. Notas sobre o conceito de empresário e empresa no código civil brasileiro. Revista Pensar, UNIFOR, Fortaleza, v. 11, p. 192-202, fev. 2006, pg. 200.

${ }^{36}$ Uma vez que a pesquisa de caso baseia-se principalmente nas diferentes interpretações acerca dos contratos inseridos na relação de distribuição de derivados de petróleo, a investigação restringiu-se aos Tribunais estaduais, não se estendendo aos julgados do Superior Tribunal de Justiça.
} 
comodato é um instrumento tipicamente civil, utilizado para que "alguém entregue a outrem alguma coisa infungível para que este dela se utilize, gratuitamente, com o encargo, porém, de restituí-la depois" ${ }^{37}$, sendo, todavia, também utilizado em outros negócios jurídicos.

Diante da definição de BEvILÁQuA, resta evidente a função tipicamente civil do contrato de comodato, uma vez que é regulado no Código Civil a partir do art. 579 até o art. 585 e estabelece a gratuidade do ato como elementar ao instituto. Dessa forma, não há, à primeira vista, possibilidade de inserção desse contrato em operações comerciais.

Entretanto, tanto a doutrina, quanto a práxis mercantil apontam a possibilidade de utilizar esse instrumento nas relações comerciais - mais especificamente, nas relações empresariais de distribuição de bebida e combustíveis ${ }^{38}$.

Daí importância da presente pesquisa, pois, se o comodato é utilizado nessas relações, principalmente associado ao contrato de distribuição, como antes realçado, é relevante destacar qual é o conjunto de normas e regras aplicáveis quando ocorre a discussão judicial desses contratos. Isto é, uma vez que a possibilidade de previsão do posicionamento dos Tribunais (previsibilidade) é questão crucial no desenvolvimento dos negócios, é extremamente importante para os empresários saber se ao contrato de comodato inserido na relação de distribuição de derivados de petróleo, apesar de tipicamente civil, podem ser aplicadas regras comerciais, dada a natureza da obrigação subjacente.

\section{RESULTADOS: INCLINAÇÃO JURISPRUDENCIAL NO SENTIDO DE EVIDENCIAR A AUTONOMIA DO DIREITO COMERCIAL}

A amostragem final consubstanciou-se em 60 acórdãos coletados nos Tribunais do Rio Grande do Sul, de São Paulo e do Rio de Janeiro. Esse conjunto, todavia, não representa apenas um determinado número: as decisões foram analisadas de forma profunda e crítica, de maneira a identificar, em cada caso, o critério utilizado para a aplicação do conteúdo normativo adequado ao contrato de comodato no contexto da relação de distribuição.

Por essa razão, preferiu-se a forma de tabelas para agrupar as decisões sob critérios semelhantes, procedimento que resultou em três tabelas finais de acordo com os seguintes critérios: (i) afirmação da autonomia do Direito Comercial, ao relativizar as regras do comodato existente no Código Civil, apesar da unificação do regime obrigacional; (ii)

\footnotetext{
37 BEVILÁQUA, Clóvis. Direito das obrigações. Rio de Janeiro: Freitas Bastos, 1936, § 95, p. 227. Apud SANSEVERINO, Paulo de Tarso. Contratos Nominados II. 2. ed. São Paulo: Revista dos Tribunais, 2011, p. 273.

${ }^{38}$ SANSEVERINO. Op. cit., p. 274.
} 


\title{
Cadernos do Programa de Pós-Graduação em Direito/UFRGS
}

aplicação das regras civis ao contrato de comodato, mesmo inserido em relação tipicamente empresarial de distribuição; (iii) análise de decisões anteriores à vigência do Código Civil de 2002

Diante dessa divisão, para não alongar o texto com comentários individuais de cada acórdão, passa-se à análise desses três grupos de casos.

\subsection{Análise das decisões que consideram o contexto de inserção do contrato para configuração da sua função social e econômica típica}

Para esse primeiro grupo de decisões ${ }^{39}$, trata-se de situações em que uma empresa distribuidora de produtos derivados de petróleo propõe a um revendedor a comercialização desses produtos e, ao celebrarem os contratos necessários para o desenvolvimento da atividade empresarial, especialmente no que toca ao contrato de comodato, essa distribuidora, segundo as decisões coletadas, não tem a intenção de gratuidade típica do instrumento.

Pelo contrário, o contrato de comodato, nesse caso, é instrumento viabilizador do

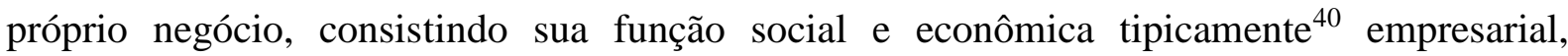
exigindo um afastamento das regras comuns e típicas do contrato de comodato civil regulado pelo Código Civil de 2002.

Assim, a consideração de que há necessidade de temperamento das regras previstas no Código Civil com princípios e regras empresarias é levada em conta em diversos acórdãos, os quais se agruparam nesse primeiro bloco. Destaca-se, nesse sentido, o entendimento no julgado cujo acórdão coube à lavra do Des. EUGÊNIO FACCHINI NETO:

\begin{abstract}
"O contrato de comodato de bens necessário ao funcionamento de um posto de combustível é um contrato especial, que se diferencia do comodato típico, em que somente o comodatário aufere vantagens e, portanto, deve assumir as despesas inerentes à restituição do bem recebido em comodato. No caso em tela, também o comodante aufere vantagens com o negócio celebrado, pois o mesmo é muitas vezes condição para viabilizar o complexo relacionamento entre as partes. Assim, diante do interesse recíproco das partes, não tendo elas disciplinado a questão das despesas relacionadas à restituição dos bens objeto do comodato, devem as mesmas serem repartidas entre ambas, por igual" 41 .
\end{abstract}

\footnotetext{
${ }^{39}$ Segue, ao final desse item, a tabela de decisões como TABELA 1.

${ }^{40}$ Para todos os efeitos, adota-se, quando falamos de tipicidade, a concepção de JOAQUIM DE SOUSA RIBEIRO. Para o Professor português, a tipicidade do contrato relaciona-se ao "desvio social típico", isto é, o contrato que, uma vez inserido num contexto fático que desvirtue sua função de ordenação da vida privada, fazendo surgir situações desiguais, sendo essas percebidas empiricamente na sociedade. RIBEIRO, Joaquim de Sousa. $O$ Problema do Contrato, as Clausulas Contratuais Gerais e o Princípio da Liberdade Contratual. Coimbra: Almedina, 2003.

${ }^{41}$ Apelação Cível No 70034883397, Décima Nona Câmara Cível, Tribunal de Justiça do RS, Relator: Eugênio Facchini Neto, Julgado em 04/10/2011.
} 


\section{Cadernos do Programa de Pós-Graduação em Direito/UFRGS}

Extrai-se do voto do magistrado que o comodato em questão "é um contrato especial", uma vez que "também o comodante aufere vantagens com o negócio celebrado", devendo "as despesas relacionadas à restituição dos bens objeto do comodato".

É relevante assinalar que, a teor do art. 584, do Código Civil ${ }^{42}$, em sendo a relação obrigacional subjacente estritamente civil, ficaria apenas por conta do comodatáriorevendedor, "serem repartidas entre ambas, por igual".

Resta claro, portanto, o realce dado pelo julgador à autonomia da relação comercial, tendo em vista a harmonização da regra civil com o contexto de inserção do contrato de comodato: uma vez que a função do instrumento é destinada para um fim ${ }^{43}$ distinto daquele preconizado pelo legislador, muda-se o substrato lógico que sustentava a orientação da aplicação normativa ${ }^{44}$.

Essa possibilidade, embora não tenha sido expressamente citada pelo magistrado na decisão supramencionada, está em plena consonância com o ordenamento jurídico estruturado pelo Código Civil de 2002. Isso porque, se por um lado o Código unificou as obrigações civis e mercantis, por outro, garantiu a "mobilidade e unidade ao sistema", a partir das cláusulas gerais e pela concepção culturalista adotada pelo Professor MIGUEL REALE - representada nas diretrizes que nortearam a redação do Projeto.

Um exemplo de cláusula geral que se adapta perfeitamente para o caso do contrato de comodato inserido na relação de distribuição de derivados de petróleo é a função social dos contratos, regulada no Código Civil pelo art. 421. A função social dos contratos atua como um limitador da liberdade de contratar, pois a identificação do elemento "social" da atividade fim de distribuição é evidentemente comercial, o que exige do julgador trocar as lentes na análise daquele contrato de comodato, uma vez que a incidência direta das regras do Código Civil que regulam esse contrato não teria o substrato imaginado pelo legislador.

\footnotetext{
${ }^{42}$ Art. 584. O comodatário não poderá jamais recobrar do comodante as despesas feitas com o uso e gozo da coisa emprestada.

43 "Segundo Bobbio, sempre que se faz uma análise normativa e se busca a "função" de um determinado instituto, esta é feita através da identificação da sua "teleologia": uma análise funcional busca descobrir "para que o direito serve e não "como é feito o direito". BOBBIO, Norberto. Dalla struttura alla funzione. Milano: Edizioni di Comunità, 1977, p. 63. Apud BRANCO, Gerson. O regime obrigacional unificado do Código Civil brasileiro e seus efeitos sobre a liberdade contratual. A compra e venda como modelo jurídico multifuncional. Revista dos Tribunais, a. 97, v. 872, jun./2008, p. 13.

${ }^{44}$ Da mesma forma entende WALD, no texto que serviu de matriz teórica para esse trabalho: "Nas hipóteses de contratos de distribuição de gasolina, o que a financiadora desejou não foi realizar um comodato, mas emprestar dinheiro e receber, como contrapartida complementar do mútuo, um direito de exclusividade na venda dos seus produtos no posto de gasolina construído pela mutuária". WALD, Arnoldo. Os contratos de concessão exclusiva para distribuição de gasolina no direito brasileiro. Estudos e pareceres de direito comercial - problemas comerciais e fiscais da empresa contemporânea. $2^{\text {a }}$ série. São Paulo: Revista dos Tribunais, 1979, p. 189.
} 
TABELA 1

Casos sobre a Aplicação de Regras Comerciais ao Contrato de Comodato

\begin{tabular}{|c|c|c|c|}
\hline Tribunal & $\begin{array}{c}\text { Tipo e Número do } \\
\text { recurso }\end{array}$ & Relator & $\begin{array}{c}\text { Data do } \\
\text { julgamento }\end{array}$ \\
\hline $\mathrm{TJ} / \mathrm{RS}$ & $\begin{array}{c}\text { Apelação Cível n. } \\
70048112650\end{array}$ & $\begin{array}{c}\text { Des. Pedro Celso Dal } \\
\text { Pra }\end{array}$ & $14 / 06 / 2012$ \\
\hline $\mathrm{TJ} / \mathrm{RS}$ & $\begin{array}{c}\text { Apelação Cível n. } \\
70034883397\end{array}$ & $\begin{array}{l}\text { Des. Eugênio Facchini } \\
\text { Neto }\end{array}$ & $04 / 10 / 2011$ \\
\hline $\mathrm{TJ} / \mathrm{RS}$ & $\begin{array}{l}\text { Apelação Cível n. } \\
70019144492\end{array}$ & $\begin{array}{l}\text { Des. Cláudio Augusto } \\
\text { Rosa Lopes Nunes }\end{array}$ & $17 / 02 / 2011$ \\
\hline TJ/RS & $\begin{array}{c}\text { Agravo de Instrumento } \\
\text { n. } 70024745556\end{array}$ & $\begin{array}{c}\text { Des. Ergio Roque } \\
\text { Menine }\end{array}$ & $02 / 10 / 2008$ \\
\hline $\mathrm{TJ} / \mathrm{RS}$ & $\begin{array}{l}\text { Apelação Cível } \\
\text { n. } 70039804604\end{array}$ & $\begin{array}{l}\text { Des. Mylene Maria } \\
\text { Michel }\end{array}$ & $27 / 09 / 2011$ \\
\hline $\mathrm{TJ} / \mathrm{RS}$ & $\begin{array}{l}\text { Apelação Cível } \\
\text { n. } 70047054226\end{array}$ & $\begin{array}{l}\text { Des. Mário Crespo } \\
\text { Brum }\end{array}$ & $13 / 02 / 2012$ \\
\hline TJ/RJ & $\begin{array}{l}\text { Apelação Cível n. } \\
2007.001 .27258\end{array}$ & Des. Elton M. C. Leme & $02 / 08 / 2007$ \\
\hline $\mathrm{TJ} / \mathrm{SP}$ & $\begin{array}{l}\text { Apelação Cível n. } \\
\text { 9232073- } \\
\text { 10.2008.8.26.0000 }\end{array}$ & $\begin{array}{c}\text { Des. Sebastião } \\
\text { Junqueira }\end{array}$ & $23 / 11 / 2010$ \\
\hline $\mathrm{TJ} / \mathrm{SP}$ & $\begin{array}{c}\text { Apelação n. 0175472- } \\
\text { 40.2008.8.26.0000 }\end{array}$ & Des. Renato Nalini & $12 / 03 / 2009$ \\
\hline $\mathrm{TJ} / \mathrm{SP}$ & $\begin{array}{c}\text { Apelação n. 9120799- } \\
\text { 12.2006.8.26.0000 }\end{array}$ & Des. Pedro Ablas & $30 / 11 / 2011$ \\
\hline $\mathrm{TJ} / \mathrm{SP}$ & $\begin{array}{c}\text { Agravo de Instrumento n. } \\
\text { 0139521- } \\
43.2012 .8 .26 .0000\end{array}$ & Des. Clovis Castelo & $03 / 09 / 2012$ \\
\hline $\mathrm{TJ} / \mathrm{SP}$ & $\begin{array}{c}\text { Apelação n. 9164477- } \\
72.2009 .8 .26 .0000\end{array}$ & Des. Carlos Nunes & $27 / 02 / 2012$ \\
\hline $\mathrm{TJ} / \mathrm{SP}$ & Apelação n. 9072930- & Des. Romeu Ricupero & $18 / 08 / 2011$ \\
\hline
\end{tabular}




\begin{tabular}{|l|c|c|c|}
\hline & 53.2006 .8 .26 .0000 & & \\
\hline TJ/SP & Apelação n. 0136880- & Des. Kiotsi Chicuta & $02 / 08 / 2012$ \\
& 9.2007 .8 .26 .0100 & & \\
\hline
\end{tabular}

\title{
2.2. Relação de decisões que aplicaram regras civis ao contrato de comodato inserido na
} relação de distribuição de derivados de petróleo

O segundo grupo de decisões ${ }^{45}$, tendo como pano de fundo a mesma situação apresentada anteriormente, isto é, a discussão judicial do contrato de comodato quando inserido na relação de distribuição de derivados de petróleo, revela uma perspectiva distinta daquela encontrada nos acórdãos já comentados.

É bem verdade que um número menor de decisões foi encontrado, se comparado com o primeiro grupo, todavia, pode-se considerar que alguns juízes interpretam ter a unificação das obrigações civis e mercantis, pelo Código Civil de 2003, promovido uma espécie de absorção do Direito Comercial pelo Direito Civil, uma vez que, na produção dos seus votos, dissociam o negócio subjacente do contrato pactuado, aplicando as regras do Código Civil ao contrato de comodato.

Essa constatação fica evidente ao lermos o trecho extraído do voto do Des. CLÁudio HAMILTON:

\begin{abstract}
"O licenciamento se refere aos estabelecimentos de venda de combustível, ou seja, aos postos de abastecimento. Nesse caso, não há razão para ser imputada responsabilidade àqueles que fornecem o combustível para a venda. Ainda que os tanques e outros instrumentos inerentes a essa atividade sejam de propriedades da ré [distribuidora], e estejam emprestados em regime de comodato, a obrigação de regularização é do empreendedor, vez que ele utilizará o referido licenciamento. Ainda, não há previsão legal ou contratual no sentido de que seria obrigação da autora a manutenção ou a substituição dos equipamentos fornecidos em comodato. Há, por outro lado, a obrigação do autor [revendedor], em conservar os equipamentos" $"$.
\end{abstract}

O excerto destacado denota ter sido a relação econômica - distribuição de combustível - desconsiderada na análise do contrato de comodato, uma vez que foram aplicadas diretamente as regras do Código Civil ao caso, incidindo na espécie o art. 582, segundo o qual o "comodatário é obrigado a conservar, como se sua própria fora, a coisa emprestada, não podendo usá-la senão de acordo com o contrato ou a natureza dela, sob pena de responder por

\footnotetext{
${ }^{45}$ Segue, ao final desse item, a tabela com as decisões como TABELA 2.

46 Apelação Cível No 9291592-13.2008.8.26.0000, 27ª Câmara de Direito Privado, Tribunal de Justiça de SP, Relator: Cláudio Hamilton, Julgado em 28/02/2012.
} 
perdas e danos. O comodatário constituído em mora, além de por ela responder, pagará, até restituí-la, o aluguel da coisa que for arbitrado pelo comodante".

Nesse sentido, procedem as angústias de VIVANTE ao temer um "grave prejuízo ao progresso do direito comercial" ${ }^{47}$, decorrente das consequências de uma unificação das obrigações civis e mercantis pelo Código Civil, tendo em vista o substrato em que estava inserido aquele contrato de comodato fora totalmente desconsiderado em prol da aplicação genérica das regras civis.

Assim, ao encontrarem-se decisões, como as constantes da Tabela 2, que desconsideram a natureza da relação obrigacional subjacente e aplicam indistintamente as regras do Código Civil, conclui-se não ter a unificação legislativa do regime das obrigações correspondido à realidade dos contratos empresariais. Isso porque, esses se diferenciam dos demais quanto à atividade que viabilizam, isto é, relações economicamente interessadas, para os quais as regras comerciais devem ser levadas em consideração.

\footnotetext{
${ }^{47}$ E prossegue: "Unificando os dois Códigos, formar-se-ia, provavelmente, um único Código de regras gerais, provido daquele tecnicismo jurídico que é o fruto mais vivo da atividade comercial; regras gerais que, por sua própria e mesma generalidade, formariam um guia muito vago para as decisões dos magistrados. Não se poderia renunciar àquela tormentosa atualização da matéria comercial sem atraiçoar, por amor da construção lógica, a construção realista". VIVANTE, Cesare. Introdução: Os comerciantes. Trad. Haroldo Malheiros Duclerc Verçosa. Revista de direito mercantil, industrial, econômico e financeiro, n. 102, abr.-jun./1996, p. 109.
} 
TABELA 2

Casos sobre a aplicação de regras civis ao contrato de comodato quando inserido na relação empresarial de distribuição

\begin{tabular}{|c|c|c|c|}
\hline Tribunal & $\begin{array}{c}\text { Tipo e Número do } \\
\text { recurso }\end{array}$ & Relator & $\begin{array}{c}\text { Data do } \\
\text { julgamento }\end{array}$ \\
\hline $\mathrm{TJ} / \mathrm{RS}$ & $\begin{array}{l}\text { Apelação Cível } \\
\text { n. } 70037890936\end{array}$ & $\begin{array}{l}\text { Des. Lúcia de Castro } \\
\text { Boller }\end{array}$ & $14 / 04 / 2011$ \\
\hline $\mathrm{TJ} / \mathrm{SP}$ & $\begin{array}{c}\text { Apelação Cível } \\
\text { n. 9149514- } \\
93.2008 .8 .26 .0000\end{array}$ & Des. Gomes Varjão & $04 / 07 / 2011$ \\
\hline $\mathrm{TJ} / \mathrm{SP}$ & $\begin{array}{l}\text { Apelação Cível n. } \\
\text { 9291592- } \\
\text { 13.2008.8.26.0000 }\end{array}$ & Des. Claudio Hamilton & $28 / 02 / 2012$ \\
\hline $\mathrm{TJ} / \mathrm{RS}$ & $\begin{array}{l}\text { Apelação Cível n. } \\
70026697623\end{array}$ & $\begin{array}{c}\text { Des. José Francisco } \\
\text { Pellegrini }\end{array}$ & $31 / 03 / 2009$ \\
\hline $\mathrm{TJ} / \mathrm{RS}$ & $\begin{array}{l}\text { Apelação Cível } \\
\text { n. } 70044548154\end{array}$ & $\begin{array}{l}\text { Des. Jorge Luiz Lopes } \\
\text { do Canto }\end{array}$ & $28 / 09 / 2011$ \\
\hline $\mathrm{TJ} / \mathrm{RJ}$ & $\begin{array}{c}\text { Agravo de Instrumento } \mathrm{n} \text {. } \\
2008.002 .12351\end{array}$ & $\begin{array}{c}\text { Des. Marco Antonio } \\
\text { Ibrahim }\end{array}$ & $20 / 05 / 2009$ \\
\hline
\end{tabular}

\subsection{Análise de decisões anteriores à vigência do Código Civil de 2002}

Cabe ainda detalhar se posicionamento jurisprudencial no que concerne à identificação da obrigação subjacente como comercial, a despeito de o contrato ser civil, como ocorre no comodato inserido na relação de distribuição de derivados de petróleo, variou consideravelmente após a vigência do Código Civil de $2002^{48}$. Outra hipótese a ser testada, refere-se à possibilidade de o Código, no que tange ao contexto ressaltado, ter concretizado posição que já vinha sendo aplicados pelos Tribunais brasileiros.

Tendo em vista que até 1990 o mercado brasileiro não estava completamente aberto, não se encontram muitas demandas judiciais que tenham como objeto contratos firmados

\footnotetext{
${ }^{48}$ Segue, ao final desse item, a tabela com as decisões como TABELA 3.
} 
entre distribuidores e revendedores ${ }^{49}$, como por exemplo, o de comodato para distribuição de derivados de petróleo.

O julgado que melhor sintetiza o montante de casos analisados nesse item refere-se à Apelação Cível n. 33796, resenhada pelo Des. CRISTIANO GRAEFF JúNIOR, no Tribunal de Justiça do Rio Grande do Sul. In casu, a discussão central tocava à possibilidade de ajustar multa devido ao inadimplemento do contrato de concessão (contrato principal), ainda que esse tenha sido convencionado em instrumentos distintos, um mútuo e um comodato. A argumentação do magistrado vai ao sentido dos outros julgados analisados: uma vez que os contratos são coligados, pois visam viabilizar a atividade de distribuição (relação econômica subjacente a todos os contratos), é lícito ajustar a multa referente ao respectivo inadimplemento.

Nesse sentido, apesar da unificação do regime das obrigações ter efetivamente ocorrido no plano legal, conclui-se a partir da leitura dos acórdãos pesquisados anteriormente à vigência do Código Civil de 2002, que a elaboração desse Diploma esteve atenta ao posicionamento jurisprudencial e à construção doutrinária até então. A principal contribuição do Código, portanto, foi cristalizar mediante os artigos relacionados à aplicação de princípios contratuais como a função social dos contratos, a possibilidade de reconhecimento pelo magistrado da relação obrigacional subjacente, se comercial por exemplo, ainda que o contrato em espécie utilizado seja tipicamente civil.

49 AMARAL, Caroline; DELGADO, Maria. Uma análise da exclusividade nas relações contratuais entre revendedor e empresa distribuidora no mercado de combustíveis. Instituto Brasileiro de Petróleo e Gás. 2005, p. 04. Disponível em: < http://www.portalabpg.org.br/PDPetro/3/trabalhos/IBP0155_05.pdf>. Acesso em: 26 de nov. de 2013. 


\section{TABELA 3}

Casos envolvendo o contrato de comodato inserido no contexto de distribuição de derivados de petróleo antes da vigência do Código Civil de 2002 do Código Civil de 2002

\begin{tabular}{|c|c|c|c|}
\hline Tribunal & $\begin{array}{c}\text { Tipo e Número do } \\
\text { recurso }\end{array}$ & Relator & $\begin{array}{c}\text { Data do } \\
\text { julgamento }\end{array}$ \\
\hline TJ/RS & $\begin{array}{l}\text { Apelação Cível, nº } \\
70001639996\end{array}$ & $16^{\mathrm{a}}$ Câmara Cível & $04 / 04 / 2001$ \\
\hline $\mathrm{TJ} / \mathrm{RS}$ & $\begin{array}{l}\text { Apelação Cível n. } \\
590072880\end{array}$ & $\begin{array}{c}\text { Des. Celeste Vicente } \\
\text { Rovani }\end{array}$ & $11 / 12 / 1990$ \\
\hline TJDFT & $\begin{array}{l}\text { Apelação Cível n. } \\
\text { 2001.01.1.057158-0 }\end{array}$ & $5^{\text {a }}$ Turma Cível & $12 / 08 / 2002$ \\
\hline $\mathrm{TJ} / \mathrm{RS}$ & Apelação Cível n. 33796 & $\begin{array}{l}\text { Des. Cristiano Graeff } \\
\text { Júnior }\end{array}$ & $09 / 10 / 1979$ \\
\hline $1^{\circ} \mathrm{TAC} / \mathrm{SP}$ & $\begin{array}{l}\text { Agravo de Instrumento } \mathrm{n} \text {. } \\
\qquad 941.027-5\end{array}$ & Des. Álvares Lobo & $08 / 08 / 2000$ \\
\hline $2^{\circ} \mathrm{TAC} / \mathrm{SP}$ & $\begin{array}{l}\text { Apelação Cível } \\
\text { n. 567956-3 }\end{array}$ & Des. Antonio Maria & 18/08/1999 \\
\hline $1^{\circ} \mathrm{TAC} / \mathrm{SP}$ & $\begin{array}{c}\text { Agravo de Instrumento } \mathrm{n} \text {. } \\
808.792-2\end{array}$ & $\begin{array}{c}\text { Des. Carlos Paulo } \\
\text { Travan }\end{array}$ & $01 / 09 / 1998$ \\
\hline
\end{tabular}

\section{UM NOVO CÓDIGO COMERCIAL É NECESSÁRIO?}

Ao refletir sobre a necessidade da formação de um corpo de leis unitário e sistematizado para alguma área do Direito, principalmente após os estudos de NATALINO IRTI que, se resumidos a uma palavra seria a sua difundida expressão "decodificação" ${ }^{50}$, deve-se ter em mente, em primeiro lugar, se o substrato histórico enseja a produção de uma nova codificação, motivado por um contexto histórico de mudança ${ }^{51}$, isto é, se há alguma particularidade histórica ou até mesmo um clamor social que justifique essa proposição.

\footnotetext{
${ }^{50}$ IRTI, Natalino. L'Età della Decodificazione. 2. ed. Milano: Giuffrè, 1979, p. 33.

${ }^{51}$ Sobre o fenômeno histórico da Codificação: "La Codificación significó para la historia jurídica, y por vez primera, un brusco cambio de sentido. El detentador del poder político demostró una psicología profundamente distinta en relación con el derecho: comprendió su importancia, se atribuyó su producción, estableció un
} 


\section{Cadernos do Programa de Pós-Graduação em Direito/UFRGS}

Isso porque, historicamente no civil law, os Códigos surgem como respostas, reações a sistemas sociais, instituições e formas de governo que não mais aderem ao substrato social existente. Daí a afirmação de VAN CAENEGEM de que "[h]istoricamente, a codificação foi uma arma contra o judiciário, ou a casta da noblesse de robe, que possuía os seus cargos e invocava nebulosos princípios gerais que não estavam escritos em lugar nenhum. Serviu também contra os doutores da lei, que brandiam citações eruditas de livros com mil anos de idade ou de outros doutores, que enterravam a justiça sob pesados tomos, cheios de contradições e que serviam apenas para desencaminhar o homem comum"52.

Mesmo que hoje essa perspectiva possa ser considerada ultrapassada, a reflexão sobre a passagem supramencionada oferece elementos para discutirmos a real necessidade de um novo Código Comercial. Nesse sentido, observemos ser o principal argumento do redator do Projeto de Lei n. 1.572/11 o da necessidade de valorização do Direito Comercial, que teria "perdido sua história" com a revogação de parte substancial do Código Comercial de 1850 a partir da vigência do Código Civil de 2002.

Ora, como visto da relação de casos analisada no presente trabalho, é de se ressaltar que o Código Civil de 2002, embora tenha unificado o regime das obrigações em um único diploma, permitiu, através da técnica legislativa das cláusulas gerais e da perspectiva de ser um "código culturalista" 53 , a necessária dinamicidade - essencial ao Direito Comercial. Este permaneceu não só com a sua história, tendo em vista o reconhecimento da autonomia substancial do Direito Mercantil ${ }^{54}$, mas também com a possibilidade de desenvolvimento contínuo, como o reconhecimento da atipicidade dos chamados contratos comerciais.

rigidísimo monopolio sobre el mismo. La experiencia jurídica, que, por lo que respecta al derecho privado, suponía efectivamente una pluralidad de ordenamientos dentro de la propia experiencia estatal, se vio obligada a coincidir con el Estado y quedó comprendida dentro de él, anquilosada". (...) "La Codificación fue todo esto también, y el historiador tiene el deber elemental de ponerlo de relieve. Lo peor, sin embargo, estaba por suceder en el plano cultural: toda esta gran operación de política del derecho que hemos llamado absolutismo jurídico, una operación de poder, históricamente relativa, de solución contingente que era propia de un juego determinado de fuerzas históricas, gracias a las potencialidades iusnaturalistas de las que se impregnó, fue proyectada hacia el paraíso de los modelos absolutos, y se convirtió en la mejor solución posible para el hoy y el mañana". GROSSI, Paolo. Absolutismo jurídico y derecho privado en el siglo XIX. Discurso para o recebimento do título "Doctor Honoris Causa" na Universidat Autònoma de Barcelona. Bellaterra, 1991, p. 13-15.

${ }^{52}$ CAENEGEM, R. C. van. Juízes, legisladores e professores: capítulos de história jurídica europeia. Trad. Luiz Carlos Borges. Rio de Janeiro: Elsevier, 2010, p. 106.

${ }^{53}$ Sobre a Codificação e a matriz culturalista do Código Civil de 2002, v. MARTINS-COSTA, Judith: "Nenhum Código provém do nada, nenhum código opera no vazio. O seu modelo sempre expressa uma reflexão e uma tomada de posição diante dos problemas do mundo - isto é, uma filosofia. As matrizes teóricas do novo Código Civil tem origem, justamente, no culturalismo de Reale, na sua concepção acerca dos modelos jurídico e da concreção, no que chama, enfim, de 'normativismo concreto'." MARTINS-COSTA, Judith. Culturalismo e experiência no novo Código Civil brasileiro. Boletim da Faculdade de Direito da Universidade de Coimbra, vol. LXXVIII, 2002, p. 604.

${ }^{54}$ Sobre a tese da autonomia substancial, v. BARROS LEÃES, Luiz Gastão Paes de. A disciplina do direito de empresa no novo Código Civil brasileiro. Revista de direito mercantil, industrial, econômico e financeiro, $\mathrm{n}$. 
Desta reflexão resulta não haver necessidade de uma sistematização própria para a consideração de regras intrínsecas a essa área do Direito. Isto é, uma vez que a relação jurídica subjacente é comercial, há, sim, institutos disponíveis aos magistrados que autorizam o afastamento da aplicação direta das regras civis em prol da conservação do Direito Comercial. Exemplo destes institutos é a função social dos contratos, explicitada na parte geral da disciplina dos contratos e, portanto, incidente inclusive sobre os contratos comerciais e os contratos a eles conexos.

Embora o Código Civil tenha trazido alguns problemas para o Direito Comercial, como o engessamento das sociedades limitadas, devido à excessiva burocratização e a consequente onerosidade desse tipo societário que é o mais utilizado entre os empresários, considera-se nessa análise não ser esse, de per si, um argumento capaz de ensejar a promulgação de um novo Código Comercial, que consegue trazer ainda mais problemas ${ }^{55}$.

\section{CONSIDERAÇÕES FINAIS}

Apesar de o Código Civil de 2002 ter concretizado uma vocação histórica do Direito brasileiro ao unificar o regime das obrigações ${ }^{56}$, isso não promoveu a absorção do Direito

128, Out./Dez. 2002, p. 09: “O Código acompanha, portanto, a tese da autonomia substancial do Direito Mercantil e adota o processo de unificação parcial do Direito Privado, na parte relativa ao Direito das Obrigações, deixando para leis esparsas as matérias que reclamam disciplina especial autônoma (in primis, falência, concorrência etc.), certo de que os institutos do chamado Direito Comercial, estejam normatizados em um Código único, conjuntamente com os de Direito Civil, ou incorporados a legislações extravagantes, sempre serão substancialmente distintos dos do Direito Civil, posto que informados por princípios próprios".

55 Apenas para não passar em branco, visto que não é o objetivo central desse artigo, alguns dos muitos defeitos do Projeto de Lei: (i) consegue retroceder 200 anos ao usar um conceito formal para considerar quem é empresário ("Art. 9. Empresário é quem, sendo pessoa física ou sociedade, está inscrito como tal no Registro Publico de Empresas.), revivendo o art. $4^{\circ}$ do Código Comercial de 1850; (ii) no art. $4^{\circ}$, o Projeto enumera uma lista de "princípios gerais" que informam todo o Código ("Art. 4. São princípios gerais informadores das disposições deste Código: I - Liberdade de iniciativa; II - Liberdade de competição; e III - Função social da empresa."). Todavia, no art. $8^{\circ}$, afasta a aplicação de todo e qualquer princípio ("Art. $8^{\circ}$. Nenhum princípio, expresso ou implícito, pode ser invocado para afastar a aplicação de qualquer disposição deste Código ou da lei.). (iii) reputa ao Ministério Público a possibilidade de anulação de qualquer negócio jurídico, caso não cumpra a função social ("Art. 317. O Ministério Publico e os demais legitimados podem pleitear a anulação do negócio jurídico, provando o descumprimento da função social. § 1o Os contratantes podem, em sua resposta, apresentar ao juiz proposta de alteração do contrato, que assegure, reforce ou re-estabeleça o cumprimento da função social. Caso a proposta seja aceita pelo juiz, a ação será extinta sem julgamento de mérito e sem condenação sucumbencial. § 20 O juiz poderá rejeitar o pedido de anulação, se considerar que o contrato empresarial implicou, ou pode implicar, benefícios para algum interesse coletivo, difuso ou individual homogêneo, superiores ao prejuízo apontado. § 30 Se acolher pedido de indenização, o juiz distribuirá a obrigação entre os contratantes, proporcionalmente ao proveito que cada um deles obteria do contrato anulado."). 56 “Confessadamente inspirado no Código Civil italiano de 1942, a ponto de repetir alguns artigos do Código peninsular relativos à disciplina da empresa (inserida no Capítulo relativo ao Direito do Trabalho), o novo Código mostra-se fiel à longa tradição do Direito brasileiro, consagrando a ideia da unificação da matéria obrigacional e inscrevendo no âmbito do Direito das Obrigações a disciplina do Direito das Empresas, 


\section{Cadernos do Programa de Pós-Graduação em Direito/UFRGS}

Comercial pelo Direito Civil, uma vez que para haver justiça, no sentido da razoabilidade das decisões nas relações comerciais, é necessária a aplicação de regras adequadas à realidade dos contratos empresariais.

Disso decorre, como visto da análise dos acórdãos supracolacionados, a constatação de que na prática houve a manutenção da autonomia científica do Direito Comercial, uma vez que a desconsideração da relação obrigacional subjacente ocasiona decisões injustas sob o ponto de vista do ordenamento jurídico vigente.

Para chegar a essa conclusão, o grupo de casos analisados exigiu corte metodológico considerável, na medida em que circunscreveu a análise das decisões aos casos envolvendo discussão a respeito do contrato de comodato inserido na relação de distribuição de produtos derivados de petróleo. Como bem ressaltou o Professor ARNOLDO WALD, no seu parecer publicado que inspirou a elaboração desse trabalho, "evidencia-se a relação entre os vários contratos, pois uns se referem aos outros, complementando-se reciprocamente, havendo, na realidade, um único negócio, embora concretizado em vários instrumentos". Ao passo que, "o contrato de financiamento contém cláusula obrigando o financiado a assinar o contrato de comodato, e este estipula que o comodatário só poderá utilizar os equipamentos para medir, guardar, vender e anunciar os produtos da financiadora, que é também a comodante (distribuidora)" ${ }^{\prime 57}$.

Nessa perspectiva, a justificativa para essa operação está justamente na complexidade dos contratos empresariais, que revelam a necessidade de um estudo aprofundado em cada caso concreto. A guisa de exemplo, o feito pelo Des. KIOITSI ChicutA, do Tribunal de Justiça de São Paulo, ao temperar o art. 582, do Código Civil, entendendo a relação empresarial subjacente ao contrato de comodato, e não aplicando literalmente a regra de que o comodante não tem responsabilidade sobre o uso do bem dado em comodato:

\footnotetext{
"Assim, tendo em vista se tratar de comodato de tanques e bombas para armazenamento e venda de produtos combustíveis e, considerando os termos do contrato firmado, a revendedora tinha o uso privativo, todavia a manutenção e reparação era de responsabilidade da distribuidora. Ademais, diante da constatação
}

considerado como um desdobramento imediato e natural daquele. De fato, a unificação das obrigações no Direito brasileiro já se mostrava praticamente instaurada em nosso meio, em pleno Império, desde o seu primeiro monumento legislativo, ou seja, o Código Comercial de 1850, cujo art. 121 estabelecia, faz mais de 150 anos, que, salvo modificações e restrições nele estabelecidas, 'as regras e disposições do Direito Civil para os contratos em geral são aplicáveis aos contratos comerciais"”. BARROS LEÃES, Luiz Gastão Paes de. A disciplina do direito de empresa no novo Código Civil brasileiro. Revista de direito mercantil, industrial, econômico e financeiro, n. 128, Out./Dez. 2002, p. 07.

57 WALD, Arnoldo. Os contratos de concessão exclusiva para distribuição de gasolina no direito brasileiro. Estudos e pareceres de direito comercial - problemas comerciais e fiscais da empresa contemporânea. $2^{\mathrm{a}}$ série. São Paulo: Revista dos Tribunais, 1979, p. 182. 
de problemas com os tanques ou sua instalação, deveria a apelante providenciar a necessária substituição, até porque proibida a comodatária de removê-los, de acordo com a disposição contratual. Vale salientar que, nos termos do pactuado, a Esso se comprometeu a emprestar ao revendedor os equipamentos e utensílios de sua propriedade, necessários e suficientes ao satisfatório funcionamento do estabelecimento, o que equivale afirmar que a apelante deveria fornecer o suporte necessário e manutenção adequada ao funcionamento da revendedora, logo, tendo a CETESB exigido a troca dos equipamentos que causaram a alegada contaminação ambiental, não vinga o argumento da apelante acerca da desnecessidade da substituição dos equipamentos, até porque pleiteada sua troca dentro do prazo determinado no contrato. ${ }^{58}$ ",

Entretanto, é relevante afirmar que esse movimento legislativo do Código Civil de 2002 não teve o intuito de absorver o direito comercial $^{59}$. Daí a importância de compreender-se a necessidade da análise da função social e econômica dos contratos empresariais, visto que essa é uma ferramenta que o próprio Código dispõe, na Parte Geral dos Contratos, para interpretação e aplicação de regras.

Ao entender a função social e econômica do contrato como sendo a finalidade típica negocial a que aquele contrato pretende desenvolver, dependendo do contexto socioeconômico a que está inserido, pode-se aplicar com mais razoabilidade as normas de direito material ${ }^{60}$. Isso ocorre no caso do contrato de comodato inserido no contexto da atividade de distribuição de derivados de petróleo, uma vez que não cabe exclusivamente ao comodatário os riscos e prejuízos dessa contratação, tendo em vista o incontestável entrosamento entre os instrumentos (contratos de financiamento para a construção de postos, de comodato de tanques e de bombas e de promessa de compra e venda para revenda de quantidades mínimas de derivados de petróleo), pois, a partir da assinatura do primeiro, os outros dois decorrem obrigatoriamente, sob pena de responsabilidade civil ${ }^{61}$.

Todavia, não decorre puramente da função social e econômica do contrato a necessidade de adimplir as obrigações acessórias ao contrato de comodato de equipamentos para a distribuição de combustíveis. Nesse sentido, como mencionado anteriormente, é a

\footnotetext{
${ }^{58}$ Apelação Cível n. 0136880-49.2007.8.26.0100.

59 "Não há, pois, que falar em unificação do Direito Privado, a não ser em suas matrizes, isto é, com referência aos institutos básicos". REALE, Miguel. Exposição de Motivos. Diário do Congresso Nacional (Seção I) Suplemento 14.09.1983, p. 98.

60 "Penso que assim ocorre porque o Código configura um sistema aberto e móvel, sendo dotado das válvulas de abertura axiologicamente orientadas. Daí que o Código enseja ao intérprete/aplicador do Direito o dever, e a responsabilidade de formular, a cada caso, a estatuição, para o que deve percorrer o ciclo do reenvio, buscando em outras normas do sistema ou em valores e padrões extra-sistemáticos, os elementos que possam preencher e especificar a moldura vagamente desenhada na cláusula geral". MARTINS-COSTA, Judith. Culturalismo e experiência no novo Código Civil brasileiro. Boletim da Faculdade de Direito da Universidade de Coimbra, vol. LXXVIII, 2002, p. 625.

${ }^{61}$ WALD, Arnoldo. Os contratos de concessão exclusiva para distribuição de gasolina no direito brasileiro. Estudos e pareceres de direito comercial - problemas comerciais e fiscais da empresa contemporânea. $2^{\mathrm{a}}$ série. São Paulo: Revista dos Tribunais, 1979, p. 183.
} 
teoria da coligação contratual que sustenta a extensão dos efeitos jurídicos para aqueles contratos "conexos" ao contrato principal, isso porque há uma "união com dependência", na qual os "contratos completam-se, formando, no caso de dependência bilateral, uma unidade econômica" ${ }^{\prime 2}$.

Por isso a importância de utilizar o próprio Código Civil para fins de aplicação das normas, uma vez que, se não se pode ignorar a unificação, também não é possível afastar a autonomia do Direito Comercial, tanto que a maioria das decisões colacionadas e aqui apresentadas consideraram que, ao contrato de comodato inserido na relação de distribuição de derivados de petróleo, não podem ser aplicadas indistintamente as regras que lhe cabem por força do Código Civil, sob pena de afastar a incidência de regras do Direito Comercial justamente numa relação tipicamente comercial, que é naturalmente distinta das premissas civis, como o caso de privilégio do credor, nas relações comerciais, em oposição ao privilégio do devedor (favor debitoris), nas relações civis.

Nesse contexto, após o período de dez anos de aplicação do Código Civil de 2002 podemos concluir que, em relação à centenária discussão a respeito da dicotomia Direito Civil - Direito Comercial, apenas houve uma "mudança nas vestes", no sentido da escolha de um novo critério para a caracterização do que é, agora, empresarial. Isso atesta a autonomia substancial do Direito Comercial, sendo a unificação formal apenas a concretização de uma tendência histórica do ordenamento jurídico brasileiro.

Além disso, a análise de casos anteriores à vigência do Código Civil de 2002 demonstra que a unificação não alterou substancialmente a lente pela qual a maioria dos magistrados utilizava para entender o contrato de comodato na relação de distribuição de derivados de petróleo. Para eles, o comodato não desempenhava seu típico papel (como contrato civil), mas sim como contrato necessário para o sucesso da atividade empresarial, devendo suas regras ser interpretadas a partir de um temperamento comercial. No Código vigente, essa possibilidade foi consagrada através do princípio da função social dos contratos, que permite a identificação da obrigação principal através da leitura da relação econômica subjacente àquela operação comercial.

Por essa razão, um novo Código Comercial que tenha como principal argumento a necessidade de resgatar a autonomia do Direito Comercial não recebe respaldo histórico para sua promulgação, nem mesmo tem clamor social para sua redação. Por essa razão, o novo Código Comercial apresentado no Projeto de Lei n. 1.572, de 2011 mais se assemelha a um

${ }^{62}$ MARINO, Francisco Paulo De Crescenzo. Contratos Coligados no Direito Brasileiro. São Paulo: Saraiva, 2009, p. 94. 
retalho de artigos muitas vezes sem coerência e coesão, porque desvinculado de uma mudança social que albergue sua edição.

\section{REFERÊNCIAS}

ASCARELLI, Tullio. Origem do direito comercial. Trad. e notas de Fabio Konder Comparato. Revista de direito mercantil, industrial, econômico e financeiro, nova série, v. 35, n. 103, jul./set. de 1996, p. 87-100.

AMARAL, Caroline; DELGADO, Maria. Uma análise da exclusividade nas relações contratuais entre revendedor e empresa distribuidora no mercado de combustíveis. Instituto Brasileiro de Petróleo e Gás, 2005. Disponível em: < http://www.portalabpg.org.br/PDPetro/3/trabalhos/IBP0155_05.pdf>. Acesso em: 26.11.2013.

BARROS LEÃES, Luiz Gastão Paes de. A disciplina do direito de empresa no novo Código Civil brasileiro. Revista de direito mercantil, industrial, econômico e financeiro, n. 128, Out./Dez. 2002, p. 7-13.

BEVILÁQUA, Clóvis. Direito das obrigações. Rio de Janeiro: Freitas Bastos, 1936.

BOBBIO, Norberto. Dalla struttura alla funzione. Milano: Edizioni di Comunità, 1977.

BRANCO, Gerson Luiz Carlos. Função Social dos Contratos: interpretação à luz do Código Civil. São Paulo: Saraiva, 2009.

O regime obrigacional unificado do Código Civil brasileiro e seus efeitos sobre a liberdade contratual. A compra e venda como modelo jurídico multifuncional. Revista dos Tribunais, a. 97, v. 872, jun./2008, p. 11-42.

CAENEGEM, R. C. van. Juízes, legisladores e professores: capítulos de história jurídica europeia. Trad. Luiz Carlos Borges. Rio de Janeiro: Elsevier, 2010.

CALDEIRA, Jorge. Mauá, Empresário do Império. São Paulo: Companhia das Letras, 1995.

CARVALHO, Orlando de. Teixeira de Freitas e a unificação do direito privado. Boletim da Faculdade de Direito de Coimbra, n. 60, 1984, p. 1-86.

ESTRELLA, Hernani. Comercialização do Direito Civil. Revista Forense, n. 185, 1957.

FERREIRA COELHO. Código Civil dos Estados Unidos do Brasil. vol. I (Formação do Direito Escrito). n. 613. Rio de Janeiro: Oficinas Gráficas do "Jornal do Brasil”, 1920.

FERREIRA, Waldemar. A História do Direito nos Cursos Jurídicos do Brasil. Revista da Faculdade de Direito da USP, São Paulo, vol. XLV, "Fascículo em honra do Professor Waldemar Ferreira", 1950, p. 429-446. 
FORGIONI, Paula A. O posicionamento dos Tribunais perante os contratos de distribuição (1980 - 2000). EAESP/FGV/NPP - Núcleo de Pesquisas e Publicações. Disponível em: <http://gvpesquisa.fgv.br/sites/gvpesquisa.fgv.br/files/publicacoes/Rel\%2043-2001.pdf>.

Acesso em 02 de ago. de 2012.

. A unicidade do regramento jurídico das sociedades limitadas e o art. 1.053 do CC. Usos e costumes e regência supletiva. Revista de Direito Mercantil, vol. 147, Jul./Set. 2007, p. 7-12.

GROSSI, Paolo. Absolutismo jurídico y derecho privado en el siglo XIX. Discurso para o recebimento do título "Doctor Honoris Causa" na Universidat Autònoma de Barcelona. Bellaterra, 1991.

. O Ponto e a Linha. História do Direito e Direito Positivo na Formação do Jurista do Nosso Tempo. Tradução de Mônica Sol Glik. Revista Sequencia, n. 51, Dez. 2005, p. 31-45.

HESPANHA, António Manuel. Panorama histórico da cultura jurídica europeia. Lisboa: Publicações Europa-America, 1997.

IRTI, Natalino. L'Età della Decodificazione. 2. ed. Milano: Giuffrè, 1979.

JUNQUEIRA DE AZEVEDO, Antônio (Org.). Princípios do Novo Código Civil Brasileiro e Outros Temas: homenagem a Tullio Ascarelli. São Paulo: Quartier Latin, 2008.

KONDER, Carlos Nelson. Contratos Conexos: Grupos contratuais, redes contratuais e contratos coligados. Rio de Janeiro: Renovar, 2006.

MAC-DONALD, Norberto da Costa Caruso. A unificação do direito das obrigações no novo código civil. Revista Síntese de Direito Civil e Processual Civil, Porto Alegre, v. 4, n. 20, nov./dez. 2002, p. 27-40.

MARCONDES, Sylvio. Problemas de Direito Mercantil. São Paulo: Max Limonad, 1970.

MARINO, Francisco Paulo De Crescenzo. Contratos Coligados no Direito Brasileiro. São Paulo: Saraiva, 2009.

MARTINS-COSTA, Judith. Culturalismo e experiência no novo Código Civil brasileiro. Boletim da Faculdade de Direito da Universidade de Coimbra, vol. LXXVIII, 2002, p. 603607.

O regime dos juros no novo direito privado brasileiro. Revista da AJURIS, Porto Alegre, v. 34, n. 105, mar. 2007, p. 237-264.

MIRAGEM, Bruno N. B. Do direito comercial ao direito empresarial. Formação histórica e tendências do direito brasileiro. Revista de Direito Privado, v. 5, n. 17, jan.-mar./2004, p. 7198.

MOREIRA ALVES, José Carlos. A Unificação do Direito Privado Brasileiro - de Teixeira de Freitas ao Novo Código Civil. In: JUNQUEIRA DE AZEVEDO, Antônio (Org.). Princípios 
do Novo Código Civil Brasileiro e Outros Temas: homenagem a Tullio Ascarelli. São Paulo: Quartier Latin, 2008.

NONATO, Orozimbo; AZEVEDO, Philadelpho; GUIMARÃES, Hahnemann. Anteprojeto de Código de Obrigações (Parte Geral), n. 2, 1941.

PEREIRA DA SILVA, Caio Mário. A unidade do direito obrigacional. Revista Forense, v. 97, p. 5.

REALE, Miguel. Exposição de Motivos. Diário do Congresso Nacional (Seção I) Suplemento 14.09.1983.

O Projeto de Código Civil: situação atual e seus problemas fundamentais. São Paulo: Saraiva, 1986.

. Visão geral do novo Código Civil. Jus Navigandi, Teresina, ano 7, n. 54, 1 fev. 2002. Disponível em: <http://jus.com.br/revista/texto/2718>. Acesso em: 13 dez. 2011.

RIBEIRO, Joaquim de Sousa. O Problema do Contrato, as Clausulas Contratuais Gerais e o Princípio da Liberdade Contratual. Coimbra: Almedina, 2003.

SANSEVERINO, Paulo de Tarso. Contratos Nominados II. 2. ed. São Paulo: Revista dos Tribunais, 2011.

SZTAJN, Raquel. Notas sobre o conceito de empresário e empresa no código civil brasileiro. Revista Pensar, UNIFOR, Fortaleza, v. 11, p. 192-202, fev. 2006.

. Codificação, decodificação, recodificação: a empresa no Código Civil Brasileiro. Revista de Direito Mercantil, vol. 143, jul./set. 2006, p. 11-20.

VIVANTE, Cesare. Introdução: Os comerciantes. Trad. Haroldo Malheiros Duclerc Verçosa. Revista de direito mercantil, industrial, econômico e financeiro, n. 102, abr.-jun./1996.

WALD, Arnoldo. Os contratos de concessão exclusiva para distribuição de gasolina no direito brasileiro. Estudos e pareceres de direito comercial - problemas comerciais e fiscais da empresa contemporânea. $2^{\text {a }}$ série. São Paulo: Revista dos Tribunais, 1979.

Submissão: 30/09/2013

Aceito para Publicação: 25/12/2013 